\title{
Obscenity, 1966: The Marriage of Obscenity Per Se and Obscenity Per Quod
}

\author{
Henry P. Monaghan*
}

In a widely admired article, Harry Kalven argued that the New York Times case ${ }^{1}$ embodies the "central meaning" of the First Amendment. On his view, in a free, open society, maximum protection must be accorded to "political" speech. 2 He concluded that the right freely to criticize the government must lie at the center of any adequate theory of the First Amendment. ${ }^{3}$

It is not so easy to make a comparable claim about the relationship between obscenity and the First Amendment. The Supreme Court's conception of obscenity is partially responsible. While the Court in Roth $v$. United States (1957) explicitly barred "obscenity" from the protection of the First Amendment, it defined the term so that only a marginal class of writings warranted the label.* Obscenity was given enough precision so that obscenity prosecutions were unlikely to result in the loss of much of value, a result which was reinforced by the Court's parallel concern with local enforcement methods-a First Amendment due process, if you will.5 In this respect, the 1966 obscenity

- Assoc. Professor of Law, Boston University. B.A. 1955, University of Massachusetts; LL.B. 1958, Yale University; LL.Mf. 1960, Harvard University.

[1.] New York Times Co. v. Sullivan, 376 U.S. 254 (1964).

[2.] Kalven, The New York Times: $A$ Note On "The Central Meaning of the First Amendment," 1964 Sup. CT. REv. 191; see also Kalven, THE Nzano ANo THE Fmst AXIENDMENT 52-64 (1965); Brennan, The Supreme Court and the Mfeililejolin Interpretation of the First Amendment, 79 HARv. L. REv. 1, 14-20 (1965); Karst, The First Amendment and Harry Kalven, 13 U.C.L.A.L. REv. 1 (1965).

[3.] Cf. Mills v. Alabama, 384 U.S. 214, 218 (1966): "Whatever differences may" exist about interpretations of the First Amendment, there is practically universal agrecment that a major purpose of that Amendment was to protect the free discussion of governmental affairs."

[4.] Roth v. United States, 354 U.S. 476 (1957). United States v. Klaw, 350 F.2d 155, $158 \mathrm{n} .2$ (2d Cir. 1965), contains a chronology of the Supreme Court's obscenity and censor: ship rulings from 1957 to 1965 .

[5.] See, e.g., Bantam Books v. Sullivan, 372 U.S. 58 (1963); Manual Enterprises, Inc. v. Day, 370 U.S. 478, 495-519 (1962) (concurring opinion). MIany of the recent decisions involved movie censorship, and from Times Film Corp. v. Chicgo, 355 U.S. 35, reversing 244 F.2d 432 (7th Cir. 1957), they culminated in Freedman v. Maryland, 380 U.S. 51 (1965); see also Trans-Lux Distributing Corp. v. Board of Regents, 380 U.S. 259 (1965), reversing 14 N.Y.2d 88, 198 N.E.2d 242 (1964). Moreover, in the free speech context, the Court has vigorously enforced the Fourth Amendment's prohibition against unreasonable searches and seizures. E.g., A Quantity of Books v. Kansas, 378 U.S. 205 (1964); Ararcus v. Search Warrant, 367 U.S. 717 (1961). In holding invalid a warrant authorizing a search for books possessed in violation of a Texas anti-subversive statute, the Court, in Stanford v. Texas, 379 U.S. 476, 485 (1965), recognized the close association between the First and 
decisions, Memoirs v. Massachusetts, ${ }^{\circ}$ Ginzburg v. United States ${ }^{7}$ and Mishkin v. New York, ${ }^{8}$ do not appear to portend fundamental changes. Attempts to suppress Eros, The Housewife's Handbook on Selective Promiscuity, and Mr. Mishkin's collection of So Firm So Fully Packed and The Strap Returns, etc., are not to be equated with the attempted suppression of Lady Chatterly's Lover, Memoirs of Hecate Gounty or Strange Fruit, all of which felt the censors' crushing heel but a few short years ago. ${ }^{9}$ Nor is the literary importance of Edmund Wilson and Lillian Smith likely to be confused with that of Ralph Ginzburg and Edward Mishkin. Obscenity litigation in 1966 remains concerned with writings of little or no importance, as it has for nearly a decade.

The foregoing analysis is, however, unsatisfying. Many people have no desire whatever to read Ulysses or Memoirs of Hecate County; their tastes run to Eros or The Strap Returns. And the 1966 decisions, even more than Roth, permit the state severely to restrict their reading fare. The existence of this governmental power of suppression demands explanation in any coherent "general theory" of the First Amendment. ${ }^{10}$

Before 1966 the crucial question in obscenity prosecutions centered on the book itself; was it obscene per se?11 The nerw rulings have added another category-a form of variable obscenity or obscenity per quod -books assumed not to be obscene per se but which because of extrinsic facts ("the circumstances of production, sale and publicity") may be treated as such. The question is whether obscenity doctrine, vintage 1966, can be reconciled with the First Amendment.

\section{Obscenity and a "General Theory" of the First Amendment}

Though others disagree, I think that in terms of result Roth stands as one of the liberal hallmarks in Supreme Court history. The important question there was not whether obscenity would be sheltered by the First Amendment, but rather how broadly that term would be

Fourth Amendments, saying that "the constitutional requirement that warrants must particularly describe the 'things to be seized' is to be accorded the most scrupulous cx. actitude when the 'things' are books, and the basis for their seizure is the ideas which they contain."

[6.] 383 U.S. 413 (1966).

[7.] 383 U.S. 463 (1966).

[8.] 383 U.S. 502 (1966).

[9.] People v. Doubleday \& Co., 297 N.Y. 687 (1947), aff'd by an equally divided Court, 335 U.S. 848 (1948) (Memoirs of Hecate County); Commonwealth v. Iscristadt, 318 Mass. 543 (1945) (Strange Fruit).

[10.] See Emerson, Toward a General Theory of the First Amendment, 72 YALE L.J. 877,938 (1963).

[11.] This was true despite the fact that the issue of the books usually arose in the context of a criminal prosecution. 
defined. It is on this point, I think, that Roth is a liberal bulwark. In an opinion by Mr. Justice Brennan, the Court explicitly rejected the view of The Queen $v$. Hicklin, ${ }^{12}$ which allowed the obscene character of a book to be judged by the effect of isolated excerpts upon particularly susceptible persons-a standard which would threaten much serious literature. The First Amendment barred such a definition, said Mr. Justice Brennan, because it protects works unless they are "utterly without redeeming social importance."13 Thus, at a minimum, any book possessing literary, artistic or scientific value could not be classified as obscene, whatever its erotic characteristics. Moreover, Justice Brennan refused to measure obscenity by the impact of isolated passages on the particularly susceptible. Rather, the inquiry must be:

whether to the average person, applying contemporary community standards, the dominant theme of the material taken as a whole appeals to the prurient interest. ${ }^{14}$

Soon thereafter Justices Harlan and Stewart added a third ingredient to the constitutional definition of obscenity: books could not be pronounced obscene unless they were patently offensive- "so offensive on their face as to affront community standards of decency."15

[12.] [1868] L.R. 3 Q.B. 360, 371.

[13.] 354 U.S. at 484 .

[14.] Id. at 489. This standard was, of course, not invented out of whole cloth. See, e.5.. United States v. Levine, 83 F.2d 156 (2d Cir. 1936); Commonwcalth v. Iscnstadt, supro note 9, at 551-52. Indeed, by the time of Roth, The Queen $v$. Hicklin had in substance already been rejected by the Supreme Court itself. See Butler v. Mfichigan, 352 U.S. 380 (1957), invalidating a Michigan obscenity statute which, in essence, measured obscenity by what was fit reading for children.

[15.] Manual Enterprises v. Day, 370 U.S. 478, 482 (1962) (opinion of Harlan. J.). Mr. Justice Harlan's opinion was concurred in only by Mr. Justice Stewart, the remaining justices deciding the case on different grounds. But Mir. Justice Harlan's vicw quickly became accepted dogma. See, e.g., Jacobellis v. Ohio, 378 U.S. 184, 192 (1964) (opinion of Brennan, J.). Later Mr. Justice Harlan elaborated his thesis, arguing that a "community cannot. where liberty of speech and press are at issue, condemn that which it generally tolerates." Smith v. California, 361 U.S. 147, 171 (1959) (concurring opinion). Since the additional criterion of "patent offensivenes" further restricted the state's power to suppress, it has rightly been viewed as a "liberal" contribution. But Mr. Justice Douglas' admonition in Rol $h$ bears repetition:

Any test that turns on what is offensive to the community's standards is too loose,

too capricious, too destructive of freedom of expression to be squared with the

First Amendment . . . This is community censorship in one of its vorst forms.

It creates a regime where in the battle between the literate and the Philistines, the

Philistines are certain to win.

354 U.S. at 512 . This is particularly true in the area of sex, because of the double standard the average man holds in this regard. "There are few topics on which the public and the private views of a person are so likely to diverge." Kalven, The Aretaphysics of the Law of Obscenity, 1960 Sur. CT. REv. 1, 45. Accordingly, "The possibility that deliberating jurors would be uncommonly sanctimonious or hypocritial seems quite obvious." United States v. Klaw, supra note 4, at 169.

I find no support for the view recently expressed by the Fifth Circuit in Chemline, Inc. v. Gity of Grand Prairie, 364 F.2d 721, 727 (5th Cir. 1966), that "appeal to prurient interests" and "patent offensiveness" are equivalent concepts. 
The crucial result of Roth seems to me beyond contradiction. No serious, complex work may be suppressed as obscene. But result is one thing, and adequacy of opinion quite another. The Court scarcely made an attempt to reconcile governmental power to repress obscenity with a comprehensive theory of the First Amendment. Nor, as a substitute, did it even construct a "special" theory for obscenity adequate to resolve future obscenity problems.

The inadequacy of Mr. Justice Brennan's opinion in Roth becomes evident from its context. When the case was in the court of appeals, ${ }^{10}$ Judge Frank, in an elaborate and learned concurring opinion, questioned whether obscenity prosecutions could on principle be reconciled with the First Amendment. He particularly attacked the assumption that obscenity triggered anti-social conduct, and argued that the supporting evidence was far too insubstantial to justify suppression. ${ }^{17}$ Framed in these terms, the constitutional question presented to the Supreme Court was most difficult: why could speech be repressed where there was no solid basis for believing that it caused immediate harm? This question raises the sharpest problems of the relationship between the legislature and the Court on civil liberties questions. A legislative finding that obscenity is harmful might fairly be inferred from the pervasiveness of obscenity legislation. But, as Dennis v. United States ${ }^{18}$ held, a legislative finding of harm cannot be conclusive on the courts in First Amendment cases, for then the First Amendment would exist only at legislative sufferance. Rather, speech may be suppressed only after a judicial determination that it presents a clear and probable danger of serious harm. ${ }^{10}$ And Judge Frank demonstrated that on the available evidence, obscenity legislation failed this test.

[16.] 237 F.2d 796 (2d Cir. 1956).

[17.] Id. at 801-27. See also Judge Frank's opinion in Roth v. Goldman, 172 F.2d 788, 790-98 (2d Cir. 1949). And see the opinion of Judge Bok in Commonwcalth $v$. Gordon, 66 Pa. D. \& C. 101 (Philadelphia County Ct. 1949). But see United States v. Klaw, supra note 4, at 163: "We do not doubt that 'obscenity" may be regulated becausc it is thought to incite antisocial sexual behavior and crime." See also id. at 165 n.11. [18.] 341 U.S. 494 (1951).

[19.] Id. at 505-08. There was no opinion for the Court, but the plurality opinion of Chief Justice Vinson for himself and Justices Reed, Burton, and Minton, expressly rejects the rule in Gitlow v. New York, 268 U.S. 652 (1925), that the courts are bound by a legislative determination that a class of speech tends to yield antisocial conscquences, unless the determination is irrational. Justices Black and Douglas, dissenting in Dennis, likewise repudiated the Gitlow rule. 341 U.S. at 579.92. Mr. Justice Clark did not participate in the Dennis decision.

However, Dennis and subsequent decisions have left uncertain the precise role of legislative findings in the First Amendment area. See generally Karst, Legislative Facts in Constitutional Litigation, 1960 SUP. Cr. REv. 75; Alfange, The Relevance of Legislative Facts in Constitutional Law, 114 U. PA. L. REV. 637 (1966). For another aspect of the general problem of the importance of legislative findings in constitutional litigation, see Katzenbach v. Morgan, 384 U.S. 64I (1966). 
The Supreme Court responded that Judge Frank had been asking the wrong questions. Obscenity, wrote Mr. Justice Brennan, is unprotected by the First Amendment not because it is harmful, but because it is worthless:

All ideas having even the slightest redeeming social importanceunorthodox ideas, controversial ideas, even ideas hateful to the prevailing climate of opinion-have the full protection of the guaranties, unless excludable because they encroach upon the limited area of more important interests. But implict in the history of the First Amendment is the rejection of obscenity as utterly without redeeming social importance. ${ }^{20}$

Judge Frank's impressive analysis was thus neatly laid to one side. But Justice Brennan's reply is perhaps a little too tidy.21

In excluding obscenity from the shelter of the First Amendment, Justice Brennan resorted to what Professor Kalven has aptly termed a "two-level" theory of speech"2 - certain classes of speech are within the protection of the First Amendment and certain classes are not. Justice Brennan sought to identify obscenity with other excluded classes of speech. He quoted from Mr. Justice Murphy's opinion in Chaplinsky v. New Hampshire: ${ }^{23}$

There are certain well-defined and narrowly limited classes of speech, the prevention and punishment of which have never been

The amicus briefs of the American Civil Liberties Union have always taken the position that obscenity cannot be suppressed absent a showing of a clear and present danger of actual harm. The Union recognizes that, as a practical matter, its position means no suppression. See, e.g., Brief of American Civil Liberties Union, p. 9 n.11, Ginzburg v. United States, 383 U.S. 463 (1966).

[20.] 354 U.S. at 484 . Mr. Justice Brennan sought to buttress this position with an historical argument, $i d$. at $482-83$, but his effort has been roundly criticized. See, e.g., Kalven, supra note 15, at 9; Memoirs v. Massachusetts, 383 U.S. at 428.31 (concurring opinion of Douglas, J.).

[21.] It should be noted here that speech put bejond the First Amendment is not thereby stripped of all constitutional protection. The Due Process Clauses of the Fifth and Fourteenth Amendments require that all governmental action be rationally related to some valid governmental end. Griswold v. Connecticut, 381 U.S. 479, 500, 502 (1960) (concurring opinions); Aptheker v. Secretary of State, 378 U.S. 500, 503 (1964). No such end served by repressing speech simply because it lacks redeeming social value. There must be some basis for believing the speech to be harmful, as false advertising is presumably harmful. Accordingly, it could be argued that the Fifth, if not the First, Amendment bars suppression of obscenity. To this analysis, there is, I think, a complete answer. Under familiar due process principles, those challenging an obscenity statute must show that the legislature could not rationally conclude that obscenity directly causes antisocial conduct. E.g., Williamson v. Lee Optial, Inc, 348 U.S. 483 (1955); sec generally McGloskey, Economic Due Process and the Supreme Court: An Exhumation and Reburial, 1962 SUP. CT. REv. 34. On the present evidence, I doubt that such a showing is possible. Cf. Memoirs v. Massachusetts, 383 U.S. at 441, 45l-54 (Clark, J., dissenting). Sec also discussion accompanying notes 16-19, supra.

[22.] Kalven, supra note 15, at 10-11.

[23.] 315 U.S. 568 (1942). 
thought to raise any Constitutional problem. These include the lewd and obscene, [the profane, the libelous, and the insulting or "fighting words"- -those which by their very utterance inflict injury or tend to incite an immediate breach of the peace]. It has been well observed that such utterances are no essential part of any exposition of ideas, and are of such slight social value as a step to truth that any benefit that may be derived from them is clearly outweighed by the social interest in order and morality. ${ }^{24}$

Interestingly, Mr. Justice Brennan's opinion omits the bracketed material from his quotation. But the omitted material is instructive, because it demonstrates that, even assuming the validity of the two-level theory, obscenity is not in fact comparable to the other classes of excluded speech. The comparison of obscenity with "fighting words" is unpersuasive, since fighting words in their nature provide a clear and present danger of social harm; they are "inseparably locked with action," as Professor Emerson notes. ${ }^{25}$ Nor is the reference to libel more persuasive. Arguably at least, libel, like fighting words, tends to inflict instantaneous, irredeemable harm; it leaves no time for counter-argument and for that reason may be discouraged. ${ }^{20}$ Moreover, the bounds of what may constitutionally be characterized as libel are being constantly narrowed. ${ }^{27}$ In any event, the classes of speech other than obscenity referred to by Mr. Justice Murphy seem positively harmful. Accordingly, they provide weak scaffolding for any theory that obscenity is beyond the First Amendment simply because it is worthless.

Second, the term "without social importance" is imprecise, and seems insufficient to rationalize all the classes of speech which the Court has held fall outside the protection of the First Amendment. Commercial promotion of goods and services is denied First Amendment protection, ${ }^{28}$ but no one thinks that commercial speech lacks social value.

[24.] Id. at 571-72. The italics appear in Mr. Justice Brennan's opinion, 354 U.S. at 485 .

[25.] Emerson, supra note 10, at 932. "Fighting words" (insults and vituperation on a face-to-face level) might have been reconciled with the traditional formulation by treating them as words which "have all the effect of force," Schenck v. United States, 249 U.S. 47, 52 (1918), or expressions "so closely brigaded with illegal action as to be an inscparablc part of it," Roth v. United States, 354 U.S. at 514 (dissenting opinion of Douglas, J.).

[26.] Emerson, supra note 10, at 922.

[27.] See, e.g., Rosenblatt v. Baer, 383 U.S. 75 (1966); Garrison v. Louisiana, 379 U.S. 64 (1964); New York Times Co. v. Sullivan, supra note 1; see also Ashton v. Kentucky,
384 U.S. 195 (1966).

[28.] The leading case is Valentine v. Chrestensen, 316 U.S. 52 (1942). Sec also Breard v. City of Alexandria, 341 U.S. 622 (1951). See generally Comment, Freedom of Expression in a Commercial Context, 78 HARv. L. REv. 1191 (1965). In Ginzburg, Mr. Justice Brennan analogized the commercial exploitation of sex to the buying and selling of merchandisc. "Material sold solely to produce sexual arousal, like commercial advertising, does not 
The reply seems to be that commercial speech plays "no essential part in the exposition of ideas"; and ideas relating to the buying or selling of goods are not "ideas" in the constitutional sense. So the social value test relates not simply to the exchange of ideas, but to the exchange of certain types of ideas, principally those related to the art of self-government.29

But the exclusion of speech not related to the exposition of ideas rests on too limited a conception of the purposes of the First Amendment. To be sure, the First Amendment is centrally concerned with protecting the untrammeled flow of political and social ideas. But Mr. Justice Brennan recognized in Roth and subsequent decisions that the First Amendment protects art and literature as well, ${ }^{30}$ although the "people do not need novels or dramas or paintings or poems because they will be called upon to vote." 31 Freedom of expression is, as Professor Emerson notes, necessarily concerned not just with public matters, but with private life, with self-fulfillment as well as self-government. ${ }^{32}$

Third, if the First Amendment excludes what is worthless, the standard of review for determining obscenity should be articulated in those terms, and those terms alone. But the Roth test turns on something altogether different-the prurient appeal of the challenged publication. Nowhere did the Roth Court explain how the prurient and social value tests related to one another. The result was that until 1966 it was impossible to say whether social value was a separate criterion, or merely some aspect or other of the prurient appeal standard. Most authorities came to believe that the two categories were independent. ${ }^{33}$ Such, at least, is the import of Mr. Justice Brennan's insistence

escape regulation because it has been dressed up as speech, or in other contexts might be recognized as speech." 389 U.S. at 474 n.17. See Comment, supra, at 1194-95.

The opinion which the Court offers in support of ... [Valentine] an be justified only on the theory that the Constitution values freedom of political propaganda more highly than it values the freedom to organize cooperation by menns of trade . . .
[This theory] is nowhere expressed in the Constitution. . [which] does not discriminate between different liberties. It leaves all liberties to compete for men's allegiance in a free field. In that competition the salesman has the same opportunity as the preacher, the scientist, the engineer, the soldier, and the politician ....

Gardner, Free Speech in Public Places, 36 B.U.L. REv. 239, 246-47 (1950).

[29.] See Roth, 354 U.S. at 484: "The protection given specch and press was fashioned to assure unfettered interchange of ideas for the bringing about of political and social changes desired by the people." See also the materials cited supra note 2.

[30.] 354 U.S. at 487; Jacobellis v. Ohio, 378 U.S. 184, 191 (1963).

[31.] Kalven, supra note 15, at 16. See also Chafee, Book Review, 62 Hanv. L. REv. 891,897 (1949).

[32.] Emerson, supra note 10, at 879.81. See also Comment, supra note 28.

[33.] In the 1966 obscenity cases all the parties and the courts below proceeded on the assumption that the constitutional standard required the Government to show: (1) prurient appeal, (2) patent offensiveness, and (3) no redeeming social value. 
in a later case that material having "any ... form of social importance ... may not be branded as obscenity," 34 apparently without regard to how pruriently appealing it is. But at least two other Justices still interpret Roth to make pruriency decisive and value irrelevant; otherwise, says Mr. Justice Clark in the Fanny Hill case, Roth gives "the smut artist free rein to carry on his dirty business." 35 Given such dis. agreements among the Justices over what Roth really held, it is probably best to say that Roth simply left the issue up in the air.

Finally, even if obscenity is itself unprotected speech, it is a term of considerable vagueness. In Roth vagueness was a principal constitutional argument: not only do obscenity statutes fail to give notice of what conduct is proscribed, but their vagueness infringes heavily on First Amendment interests by encouraging censors' attempts to suppress protected speech. The Court frankly conceded that obscenity was by no means a precise term. ${ }^{36}$ But it accepted a measure of vagueness here that it had refused to tolerate anywhere else in the First Amendment area. ${ }^{37}$ The Court recognized that it was not dealing with a simple, colorless problem of "worthless" speech, but with a problem about which there are deep-and-irrational feelings. Its sole response (albeit an important one) was that only materials "utterly without redeeming social importance" could be suppressed.38

In sum, Roth insulates from prosecution any serious or complex work, and is therefore a contribution of considerable importance. But Roth does not fit obscenity prosecutions within any general theory of the First Amendment; the social value test does not provide an adequate explanation either historically or on principle. And in no event does the social value test explain why speech dealing with sex alone

[34.] Jacobellis v. Ohio, supra note 30 , at 191.

[35.] 383 U.S. at 441 (dissenting opinion); cf. White, J., dissenting, in Fanny Hill, id. at 461 .

[36.] 354 U.S. at 491-92.

[37.] In Marcus v. Search Warrant, 367 U.S. 717, 729-31 (1961), the Court noted that the "complexity of the test fashioned in [Roth]" required discriminations of the most sensitive nature, and were wholly inconsistent with broad, clumsy local police enforcement techniques. See also People v. Kimmel, _- Ill.2d —, 217 N.E.2d 785, 786 (1966); A Quantity of Books v. Kansas, 378 U.S. 205, 210 (1964); Bantam Books, Inc. v. Sullivan, 372 U.S. 58,66 (1963).

[38.] It is interesting to note that the Court has been unwilling to accept "novel" or "new" definitions of obscenity. Winters v. New York, 333 U.S. 507, 519 (1948); sce BERNs, FREedom, VirTue and THE FIRST AMENDMENT 38-39 (pb. ed. 1964). And the Court has refused to accept analogous terminology as constitutionally sufficient. For example, stan. dards such as "sacrilegious," "immoral," "tending to corrupt morals," "harmful," and "prejudicial to the best interests of the people of [the] . . City," have all been invalidated. Superior Films, Inc. v. Dep't of Educ., 346 U.S. 587 (1954); Gelling v. Texas, 343 U.S. 960 (1952); Joseph Burstyn, Inc. v. Wilson, 343 U.S. 495 (1952). It is, in fact, most doubtful "whether any standard other than obscenity could stand the Constitutional test." United States v. Klaw, sispra note 4 , at 163 . 
shoulders the burden of showing that it is not worthless. Moreover, the Roth approach to obscenity focuses exclusively on the nature of the publication itself. By not addressing itself to such questions as why a distinction should be drawn between public and private obscenity, or between commercial exploitation of sex and the sale of the same material for scientific study, ${ }^{39}$ the Court simply postponed to another day problems which cannot be adequately resolved within the simple per se framework of Roth.

The 1966 obscenity cases mark a recognition of Roth's inadequacies and the beginnings of a recasting of doctrine. Does the revamped doctrinal structure fit more easily into a comprehensive theory of the First Amendment? Any answer must begin by assessing the possible governmental interests in suppressing obscenity. Probably no single purpose underlies obscenity legislation. Like most legislation, obscenity laws rest on views and policies which are not only inarticulate but imperfectly understood. Nonetheless, three kinds of state policies may be distinguished for the sake of analysis.

\section{The Nuisance Interest}

Public sexual conduct may offend community sensibilities, and few, if any, doubt the state's porver to prosecute public indecency or public exposure. It has been suggested that obscenity prosecutions vindicate similar interests, that offensive and aggressive marketing of sexually arousing materials is a "nuisance." ${ }^{0}$ This analysis has something to commend it, and is reflected in part in the 1966 decisions. ${ }^{11}$ But it hardly explains the pervasive character of obscenity legislation that generally makes no distinction between publicly and privately dis-

[39.] For example, assume a book is declared obscene in a decision aflirmed by the Supreme Court. An accredited institution purchases the book as part of scientific or sociological investigation. Such sales would be characterized as outside the purpose of the obscenity statute, e.g., United States v. 31 Photographs, 156 F. Supp. 350, 357-58 (S.D.N.Y. 1957); see also Redmond v. United States, 384 U.S. 264 (1960). But could cither the seller or the buyer constitutionally be prosecuted for this conduct? The answer is generally assumed to be no. But if this is the answer, is prosecution precluded because the material is not obscene in this context? see Lockhart \& Mrclure, Obscenity Censorship: The Core Constitutional Issue - TWhat is Obscene? 7 UTAH L. REv. 289, 298-302 (I961). Or is prosecution precluded because in certain contexts obscenity is constitutionally protected? Schwartz, Morals Offenses and the Model Penal Code, 63 Colus. L. REv. 669, 679-80 (I963). The 1966 obscenity cases do not answer these questions.

[40.] See, e.g., Emerson, supra note 10, at 938-39; Gerber, A Suggested Solution to the Riddle of Obscenity, 112 U. PA. L. REv. 834, 847 (1964). The brief filed in Ginzburg $v$. United States, supra note 7 , by the Authors League of America Inc., p. 5 , argued that obscenity statutes may not be applied "where a book or other publication-regardless of content-is sold to adults and where it is published and disseminated in a manner that does not invade the right of privacy of individual citizens."

[41.] $C f$. Ginzburg v. United States, 383 U.S. at 470. 
seminated erotica, or between invited and uninvited commercial exploitation. It is, after all, one thing to prevent a man from being accosted on the public streets by a seller of erotica; it is quite another matter when that man is a customer who enters the seller's bookstore or answers his ad. In this context the nuisance argument is trivial. ${ }^{42}$ Moreover, a nuisance analysis does not jibe with the Roth per se approach, which focuses simply upon the book itself, not its manner of dissemination.

\section{Anti-Social Conduct}

The time-honored rationale for censorship asserts that obscenity triggers anti-social conduct, particularly violent crimes. As Judge Frank observed, this proposition has never found substantial evidentiary support. ${ }^{43}$ To be sure, Mr. Justice Clark believes that such evidence does exist, but he concedes that opinion is divided on the point, and an examination of his affirmative sources-which include J. Edgar Hoover and Cardinal Spellman-is unpersuasive. ${ }^{44}$ The evidence in favor of a direct, immediate connection between obscenity and criminal behavior is no more compelling now than when Judge Frank wrote his concurrence. Indeed, in the 1966 cases, the United States made no attempt to argue the point, contenting itself to say that opinion is "sharply divided" on the question; ${ }^{45}$ the excellent brief for the State of New York disavowed any reliance on the supposed connection. ${ }^{46}$ And some argue that obscenity is not only harmless, but it has "redeeming social importance" by providing a harmless escape for sexual frustrations-it dissipates rather than unleashes anti-social acts. ${ }^{47}$

\section{Preservation of Character}

Finally, the state may seek to prevent the long-range effect of obscenity on character. The argument is not that obscenity generates immediate anti-social conduct, but that, like group libel, it has an

[42.] See Kalven, supra note 15, at 42.

[43.] In addition to Judge Frank's impressive opinion in Roth, $237 \mathrm{~F} .2 \mathrm{~d} \mathrm{795,} 801$ (2d Cir. 1956), sce, e.g., ThE INSTITUTE For Sex ReseARch, INC., SEx OFFENDERS 126.27, 669.92 (1965); Murphy, The Value of Pornography, 10 WAYNE L. REv. 655 (1964); Cairns, Paul \& Wishner, Sex Censorship: The Assumptions of Anti-Obscenity Laws and the Empirical Evidence, 46 MINN. L. REv. 1009 (1962). A recent murder trial in England has stirred considerable interest in the question whether obscenity triggers crime. Sec N.Y. Timcs, June 12, 1966, Literary Supplement, p. 8.

[44.] Memoirs v. Massachusetts, 383 U.S. at $451-54$ (dissenting opinion).

[45.] Brief for Respondent, p. 15, Ginzburg v. United States, supra note 7.

[46.] Brief for Appellee, pp. 64-66, Mishkin v. New York, supra note 8.

[47.] See Murphy, supra note 43, at 660-61; E. Kronhausen \& P. Kronuausen, PornocRAPHY AND THE LAW 273-74 (1959). 
insidious effect on character, gradually predisposing individuals toward deviant conduct, sexual or otherwise. ${ }^{18}$

The "character" analysis was first advanced by Mr. Justice Harlan in $R o t h{ }^{49}$ and it is the subject of a stimulating article by Professor Louis Henkin. ${ }^{50}$ There are, however, significant differences between the two arguments. Justice Harlan seems impressed with the state's interest in the prevention of character change because of its possible long-range effect on conduct. But even if obscenity can alter character, so can innumerable other stimuli, and Justice Harlan does not explain why the state has a peculiar interest in shielding character from change through obscene expression alone. Nor is his analysis consistent with Kingsley Pictures v. New York, 51 where the Court vetoed New York's attempt to bar a showing of Lady Chatterly's Lover because it depicted adultery as desirable conduct under the circumstances. Mr. Justice Stewart wrote that New York had "struck at the very heart of constitutionally protected liberty" in attempting to shield the character of its citizens from change through exposure to attacks on present standards. ${ }^{52}$ Presumably, therefore, the First Amendment protects a direct appeal for character change which falls short of incitement to specific conduct, and there is very little evidence that the obscenity directly incites to action. ${ }^{53}$

Professor Henkin pushes the analysis considerably further. He argues that obscenity legislation is designed to shield character from corrupting influences, not because such change would ultimately result in proscribable conduct, but because communities seek to preserve the traditional morality. ${ }^{54}$ What is more, Professor Henkin is satisfied that the traditional morality is quasi-religious in origin, and he is concerned

[48.] See Kalven, op. cit. supra note 2, at 14. A related but somewhat different concept stresses the impact of obscenity on personality. Obscene materials are said to create feelings of shame, guilt and morbidity; thus, they constitute a source of p5ychologial tension and anxiety. Cf. Monec Penal Code, $\$ 207.10$ (Tent. Drait No. 6, 1957), pp. 5 et seq. At present, the evidence in support of this view is insubstantial. Sec Cairns, Paul \&: Wishner, supra note 43, at 1031-34; and see note 47 supra. Such a weakly supported "mental health" argument does not seem sufficient as an independent basis for repressing speech except, perhaps, to the extent that speech may be suppressed to promote "char-

[49.] 354 U.S. at 502 .

[50.] Henkin, Morals and the Constitution: The Sin of Obscenity, 63 Colus. L. REv. 391 (1963).

[51.] 360 U.S. 684 (1959).

[52.] Id. at 688 .

[59.] See Kalven, supra note 15, at 28-30.

[54.] Henkin, supra note 50, at 395. Compare BERss, op. cil. supra note 38, which, following Plato and Aristotle, argues that the aim of the State is to develop virtuous citizens and that the First Amendment is wrongly interpreted if construed to deny the state power to promote the moral development of its citizens. 
that the legislation violates our concepts of separation of church and state as well as freedom of speech..$^{65}$

From these premises Professor Henkin concludes that discussion of obscenity has focused on the wrong issues. For him, the issue is substantive due process, not free speech: can the state enforce the morality of the community without showing that this enforcement serves some independent, "utilitarian" aim? $?^{60}$ He suggests that it cannot. ${ }^{57}$

I do not find Professor Henkin's analysis persuasive. It may be conceded that much morals legislation, including obscenity legislation, was not and is not passed for "utilitarian ends," but as Professor Hienkin recognizes, "If the challenge had been seriously pressed, some utilitarian reason for these laws might have been found." 58 Most, if not all, morals legislation, including that relating to obscenity, can be assigned reasons falling within an accepted "utilitarian" framework. Mr. Henkin's only response is that these reasons "would have been rationalizations and might have been recognized as such." 50 This is no answer, unless we are willing to abandon the "minimum rationality" standard of due process cases, ${ }^{60}$ and to permit the Court, in the fashion of Lochner $v$. New York, ${ }^{61}$ to pass on the "real" purposes of the legislation.

Moreover, even if we were to structure the question baldly in terms of the state's power to enforce the secular morality, is it not rational for a community to decide to enforce that morality so as to preserve the community's moral cohesiveness? ${ }^{32}$ Following Mill, some liberals sug-

[55.] Henkin, supra note 50, at 407-11.

[56.] Id. at $392,395-401$.

[57. His argument is that the "consumer of private immorality" may be constitu. tionally protected so long as there is no showing of danger to others. Id. at 401.07. The ancient property maxim, sic utere tuo, is resurrected as the appropriate limitation on governmental power restricting individual liberty. Id. at 403. Professor Henkin might also have observed that generally

there has been no legislative attempt to suppress publication on the ground that a book might impair moral standards by the depiction, or advocacy, of cruclty, avarice, dishonesty or cowardice. The sexual virtue is the only virtue on whose bchalf we are asked to give up the right of free expression in art or literature. The statutes do not seek suppression in the interest of honesty, kindness or courage.

Supplemental Brief of Appellants, pp. 2-3, Memoirs v. Massachusetts, supra note 6.

[58.] Henkin, supra note 50, at 404 .

[59.] Ibid.

[60.] See, e.g., Williamson v. Lee Optical Co., supra note 21; Railway Express Agency v. New York, 336 U.S. 106, 109 (1949). See also Karst, supra note 19, at 86-88; McCloskcy, supra note 21.

[61.] 198 U.S. 45,64 (1905).

[62.] See Eugene Rostow, The Sovereign Prerogative 68.69 (1962). See also Dworkin, Lord Devlin and the Enforcement of Morals, 75 YALE L.J. 986, 1003-01 (1966). As Pro. fessor Henkin recognizes, the Supreme Court has traditionally assumed that the states have wide power in the areas of moral legislation, although, as he points out, no distinction between "public" and "private" conduct scems to have been considered. See, e.g., Mugler v. Kansas, 123 U.S. 623, 662 (1887); Stone v. Mississippi, 101 U.S. 814, 818 (1880). In Winters v. New York, 333 U.S. 510,515 (1947), the Court said: 
gest that it is improper for government to interfere with individual liberty except to restrain conduct threatening others. ${ }^{.3}$ But the Constitution no more enacts Mill's Essay on Liberty than it did Herbert Spencer's Social Statics. Professor Henkin recognizes that the state may "promote general economic or social welfare." ${ }^{\circ t}$ To what end? To promote the dignity and full development of its citizens. Does the constitution, then, forbid the state to promote-even define-virtue among its citizens? I think not. With Mr. Justice Douglas, "I assume there is nothing in the constitution which forbids [a state] from using its power . . . to proscribe conduct on the grounds of good morals."

Unlike most other "morals" legislation, however, obscenity involves not conduct, but speech. ${ }^{66}$ And whatever the state's interest, the state

Acts of gross and open indecency or obscenity, injurious to public momls, are indictable at common law, as violative of the public policy that requires from the
offender retribution for acts that flaunt accepted standards of conduct. . . When a legislative body concludes that the mores of the community all for an extension of the impermissible limits, an enactment aimed at the evil is plainly within its power, if it does not transgress the boundaries fixed by the Constitution for freedom of expression.

See also, Harlan, J., dissenting, in Poe v. Ullman, 367 U.S. 497, 545-46 (1961). See generally BERNs, op. cit. supra note 38 . But there are limits on the state's power to enforce the secular morality-at least as to the methods of enforcement chosen. See Griswold v. Connecticut, 381 U.S. 479 (1965).

[63.] Mr. Justice Holmes stated the position most succinctly: "For the most part, the purpose of the criminal law is only to induce external conformity to rule." Holsues, The COMmon LAw 49 (1881). But see BerNs, op. cit. supra note 38.

[64.] Henkin, supra note 50.

[65.] Roth v. United States, 354 U.S. at 512 (dissenting opinion) (italics in original). Mr. Justice Douglas' statement was made in reference to Congressional power over the mails, but he seems to have viewed it as having general applicability.

[66.] I do not believe that those who analyzed obscenity in terms of free speech rather than substantive due process erred. To be sure, obscenity, like all "morals" legislation, presents questions of substantive due process. But under traditional conceptions of due process the questions do not seem to me difficult. On the basis of the present cvidence, I think that a legislature could rationally believe that obscenity triggers anti-social conduct, both immediately and in the long run, contributes to psychosexual tensions harmful to mental health, and diverts the reader from more socially bencficial concerns. For me, that is the end of the due process argument. Professor Henkin secms to me to be suggesting that the minimum rationality standard of the regulatory cases be abandoned in favor of a standard approaching that obtaining in the first Amendment area. Brosdly stated, that standard is a "balancing" one, and, in essence, requires that legislation significantly impinging on First Amendment interests be narrowly drawn to meet the specific evil, and that the evil to be corrected be a substantial one. There are, however, some who believe that this "balancing" test should apply only to so-alled "indirect" restrictions on speech and not to "direct" or "pure" speech, the latter being suppressible only upon a showing of clear and present danger. See Black, J., dissenting, in Barenblatt v. United States, 360 U.S. 109, 141 (1959). For our purposes it is unnecessary to determine whether, particularly in view of Dennis v. United States, 341 U.S. 494 (1951), the clear and present danger test is at most simply only another version of the balancing test, or whether its real demise is indicated by the fact that it is often not cmployed even where "direct" restrictions on speech are involved. See Kalven, supra note 2, at 213-14; Mills v. Alabama, supre note 3 . Suffice it to say here that under any view of the First Amendment there must at least be a "substantial" state interest involied before the First Amendment interest can be suppressed.

I might add that the minimum rationality standard of the regulatory cases scems to have 
cannot shield that interest from ideological assault. ${ }^{\circ 7}$ If the state cannot suppress advocacy of change, I fail to see why it may shield itself from images which in turn arouse one to question or reject his present view. ${ }^{68}$

been abandoned in favor of a First Amendment approach in the equal protection arca insofar as "personal" rights are concerned. Compare cases cited stupra note 60 with Harper v. Board of Election, 383 U.S. 663 (1966); Schneider v. Rusk, 377 U.S. 163 (1964). And this development also has a clear foothold in "straight" substantive due process cases, as the concurring opinions in Griswold v. Connecticut, supra note 62, make clear. Cf. Zemel v. Rusk, 381 U.S. I (1965).

[67.] The First Amendment is clearly relevant as an additional limitation on State power.

I can understand . . . programs of civic groups and church groups to protect and defend the existing moral standards of the community. ... When speech alone is involved, I do not think that government, consistently with the First Amendment, can become the sponsor of any of these movements. . . . [If the first amendment] is to mean anything in this field, it must allow protests even against the moral code that the standard of the day sets for the community.

Douglas, J., dissenting in Roth, 354 U.S. at 512-13. It is here that I think BERNs, op. cil. sitpra note 38, errs. He does not attach sufficient importance to the First Amendment as a limitation on the state's power over the virtue of its citizens.

[68.] Two recent decisions have raised the problem of private immorality in an obscen. ity context. In Redmond v. United States, 384 U.S. 264 (1960), a husband and wife werc convicted under the federal obscenity statute for mailing negatives and receiving through the mails developed films of each other posing in the nude. Their convictions werc vacated by the Supreme Court on the suggestion of the Solicitor General that, as a matter of policy, the statute was enforced only against "repeated offenders." Mr. Justice Stewart, with whom Mr. Justice Black and Mr. Justice Douglas concurred, filed a brief memorandum stating that they "would reverse this conviction not because it violates the policy of the Justice Department but because it violates the Constitution." Id. at 265. Less than a month later the California Supreme Court reversed on statutory grounds a trial court instruction that a jury could find the defendant guilty of possessing obscene materials even if he had prepared the materials without any intent to distribute. In re Klor, 51 Cal. Rptr. 903, 415 P.2d 791 (1966). In dicta, the court suggested that a statutc making mere possession a crime would be unconstitutional. Id. at 906, 415 P.2d at 794. See also Mapp v. Ohio, 367 U.S. 643, 673 (1961) (dissenting opinion).

If one accepts the traditional minimum rationality standard, I cannot takc seriously a notion that either of these convictions if upheld would have violated due process. Nor does any of the judges address himself in those terms to the questions presented. I suspect that Justices Black and Douglas in Redmond grounded their opinions on the view they take of obscenity prosecutions and the First Amendment, particularly since Mr. Justice Black does not recognize a general substantive due process. See Griswold v. Connecticut, supra note 62, at 507 et seg. (dissenting opinion). Mr. Justice Stcwart's view probably reflected his belief that the nude photographs were not hard core pornography. The California Supreme Court explicitly stressed First Amendment considerations. It cited Chief Justice Warren's opinion in Roth and relied on Ginzburg for its statement that no "constitutionally punishable conduct appears in the case of an individual who prepares material for his own use or for such personal satisfaction as its creation affords him," and it went on to say:

Nor does such conduct occur if the creator intends to purge the material of any objectionable element before distributing or exhibiting it. To hold otherwise would pose grave technical difficulties for the unconventional artist and would, because of the risk of criminal sanctions, tend to suppress experimental and tentative produc tions that might become, in finished form, constitutionally protected communication. 51 Cal. Rptr. at 906, 415 P.2d at 794. 


\section{The 1966 Decisions}

\section{Memoirs v. Massachusetts ${ }^{69}$}

The Fanny Hill case presented for review an attempt by the Commonwealth to suppress John Gleland's Memoirs of a Woman of Pleasure. ${ }^{70}$ History seemed to be repeating itself, for the Massachusetts court's determination that Fanny Hill was obscene mirrored the position it adopted in 1821 when first confronted with the book. ${ }^{71}$ (There was some movement, however; on this round, three of the seven Justices of the Massachusetts Supreme Judicial Court dissented.) On appeal, the Supreme Court reversed.

The Fanny Hill case was a classic model of the old obscenity proceeding; the sole question was the nature of the book itself, without regard to the conduct of those who published or sold it. As Mr. Justice Brennan noted in writing for himself, the Chief Justice, and Mr. Justice Fortas, neither party had presented evidence on the "manner and form of ... publication, advertisement, and distribution."i2 In the context, the Supreme Judicial Court's admission that Fanny Hill had a modicum of social value necessitated reversal; the book could not be suppressed, wrote the Justice, unless it were found to be utlerly without redeeming social value. ${ }^{73}$ Given the importance Mr. Justice Brennan seemed to attach to this pronouncement, it is surprising that he did not go on to consider how much social value Fanny Hill did have, or even to explain what "social value" is."it

[69.] Supra note 6.

[70.] 349 Mass. 69, 206 N.E.2d 403 (1965).

[71.] Commonwealth v. Holmes, 17 Mass. 271 (1821). See Mremoirs v. Massachusetts, 383 U.S. at 425 n.l (Douglas, J., dissenting).

[72.] 383 U.S. at 417 .

[73.] Id. at 419 . (Emphasis in original.)

[74.] Mr. Justice Brennan said:

Under this definition, as elaborated in subsequent cases, three elements must coalesce: it must be established that (a) the dominant theme of the material talien as a whole appeals to a prurient interest in ser; (b) the material is patently offensive because it affronts contemporary community standards relating to the description or representation of sexual matters; and (c) the material is utterly without redeeming social value.

383 U.S. at 418.

Mr. Justice Stewart concurred in the result on the basis of his dissenting opinion in Ginzburg, 383 U.S. at 421; and he there noted that cach of the three critcria announced by Mr. Justice Brennan must be satisfied, 383 U.S. at 499. Mr. Justice Douglas', coneurrence in Fanny Hill is in 383 U.S. at 424. Mr. Justice Black concurred, 383 U.S. at 42I, on the basis of his dissenting opinions in Ginzburg and Mishkin, 383 U.S. at 476, 515. Justices Clark, Harlan and White dissented. Despite Mr. Justice Brennan's failure 10 discuss the social value question, his reaffirmation of the test is signifieant. He explicilly rejected the view that a book's value is to be "balanced" against its other characteristics, as Mr. Justice Clark suggested. 383 U.S. at 419-20. Mrr. Justice Clark, on the other hand, denied that the social value test was even a part of the constitutional definition of obscenity. 
Perhaps the abstractness of the judicial discussion stemmed from the narrow confines of the proffered evidence. The case presented no questions on a crucial part of the obscenity problem-the commercial exploitation of erotica. At this juncture Mr. Justice Brennan first considered, by way of dictum, the possibility that such additional evidence might have been determinative.

It does not necessarily follow from this reversal that a determination that Memoirs is obscene in the constitutional sense would be improper under all circumstances. On the premise, which we have no occasion to assess, that Memoirs has the requisite prurient appeal and is patently offensive, but has only a minimum of social value, the circumstances of production, sale, and publicity are relevant in determining whether or not the publication or distribution of the book is constitutionally protected. Evidence that the book was commercially exploited for the sake of prurient appeal, to the exclusion of all other values, might justify the conclusion that the book was utterly without redeeming social importance. It is not that in such a setting the social value test is relaxed so as to dispense with the requirement that a book be utterly devoid of social value, but rather that, as we elaborate in Ginzburg $v$. United States, . . . where the purveyor's sole emphasis is on the sexually provocative aspects of his publications, a court could accept his evaluation at its face value. ${ }^{75}$

\section{Ginzburg v. United States ${ }^{78}$}

The idea that the manner in which the book is marketed-its manner of production, distribution and advertising - could be dispositive in a case moved from the level of dictum in Fanny Hill to holding in Ginzburg. Here the defendent was convicted on twenty-eight counts of violating the federal obscenity statute by mailing Eros (a hard-cover

Id. at 441-43. His rejection of the social value test as an independent standard is interest. ing; he scems to view social value as an ingredient of prurient appeal, which is to bc determined by striking a balance between the book's erotic appeal and its "mosstge." IIl. at 442-43. In this respect, I think Mr. Justice Clark is clearly in error. Sce Pcople v. Bruce, 31 Ill.2d 459, 461, 202 N.E.2d 497, 498 (1964). Mr. Justice Clark fails to appreciate that the underpinning of Roth was that obscenity could be suppressed only because it was worthless. Accordingly, as Professor Kalven long ago noted: "If the obscene is cone stitutionally subject to ban because it is worthless, it must follow that the obscene can include only that which is worthless." Kalven, supra note 15, at 13.

Mr. Justice White apparently takes a view similar to that of Mr. Justice Clark, 883 U.S. at 460-62. What conclusion he draws from treating social value as an aspect of prurient appeal is, however, unclear from his brief and somewhat unfocused opinion.

[75.] 383 U.S. at 420 . It should be noted that Mr. Justice Brennan here citcd the per quod aspects as relevant only to the question of social value, not to those of pruriency and patent offensiveness. That limitation is abandoned in Ginzburg. See text accompanying note 84 infra.

[76.] Supra note 7. 
magazine dealing in "literary pornography"), Liaison (a bi-weekly newsletter digesting articles on sex), and The Housewife's Handbook on Selective Promiscuity (an autobiography recounting the author's sexual history and philosophy in great detail). ${ }^{77}$

The Supreme Court upheld Ginzburg's conviction; speaking for the majority, Mr. Justice Brennan said that in addition to the testimony centering on the books themselves, there was

abundant evidence to show that each of the accused publications was originated or sold as stock in trade of the sordid business of pandering - "the business of purveying textual or graphic matter openly advertised to appeal to the erotic interest of their customers."78

Here was the crucial shift in theory. The language quoted by Justice Brennan is taken from the brief concurring opinion of Chief Justice Warren in Roth. In that opinion the Chief Justice made plain that in his view the "conduct of the defendant is the central issue, not the obscenity of a book or picture."79 To put it differently, such prosecutions are concerned with the suppression of dirty businesses, not dirty books. The Chief Justice had no doubt that destruction of the business of exploiting erotica lay within the state's power. But, except for a passing bow at the nuisance theory, Mr. Justice Brennan makes no effort whatever to identify the state's interest in curtailing this business. ${ }^{80}$ Simply to denounce it as a "sordid business" is not enough..$^{81}$ One suspects that the Court's consistent refusal to face the question of

[77.] The federal state is 18 U.S.C. $\S 1461$ (1964), which bars use of the mails both to "every obscene, lewd, lascivious, indecent, filthy or vile article, matter, thing, device, or substance," and to every publication describing where the foregoing may be obtained. See also I8 U.S.C. \$\$ 1462-65. For a comprehensive analysis of federal obscenity legislation see United States v. Klaw, supra note 4, at 160-63.

The verdict and judgment of the trial court are reported at 224 F. Supp. 129 (E.D. $\mathrm{Pa}$. 1963), aff'd, $338 \mathrm{~F} .2 \mathrm{~d} 12$ (3d Cir. 1964). On this and related subjects, AIr. Ginzburg has provided us with some remembrances of things past in an intervicw with Playboy Magazine, July 1966, p. 47.

[78.] 383 U.S. at 467 .

[79.] Roth v. United States, 354 U.S. at 495 (concurring opinion).

[80.] Nor did the Chief Justice in Roth. He simply said: "That there is a social problem presented by obscenity is attested by the expression of the Iegislatures of the fortyeight states as well as the Congress." 354 U.S. at 495 . No effort was made to describe the nature of the "social problem."

[81.] See Epstein, The Obscenity Business, The Atlantic Mronthly, August 1966, p. 59: In its choice of such prejudicial epithets as "pandering" and "the Icer of the sensualist" to describe Ginzburg's activities, the Court seems to be saying that Ginzburg's crime was no more than a function of his personality or character: that he was a vulgarian, and that therefore he had no right to trade in a market whose delicate and dangerous products must be limited only to gentlemen and scholars. Such an ad hominem judgment can hardly have been what the Court intended. ... 
the nature of the state's interest rests on its feeling that any such attempt would open a Pandora's box..$^{82}$

From the foregoing premise, the result in Ginzburg was inevitable. The "leer of the sensualist" permeated Ginzburg's entire operation, particularly his advertising. ${ }^{83}$ And this evidence, Mr. Justice Brennan concluded, was relevant not only to the issue of redeeming social importance as it had been in the Fanny Hill dictum, but to the issues of prurient interest and patent offensiveness as well. ${ }^{84}$

At several places in the opinion, the Court indicates that the "variable" or "per quod" factors of production, sale and advertising are to be considered only in "close" cases. ${ }^{85}$ This illustrates one of the difficulties of Roth: if a book must be "utterly without redeeming social importance" and if one emphasizes "utterly," as Mr. Justice Brennan does in Fanny Hill, ${ }^{86}$ it is difficult to imagine how the question of social value vel non can be analyzed in terms of close cases. "Utterly" seems to presuppose that the question is not one for dispute-that a book is not "utterly" beyond the pale unless no reasonable man could fairly conclude that it had social value, and thus "close cases" should be accorded constitutional protection.

Moreover, it is interesting to note what the Court found by way of a close case. Judging by Roth, Eros was not a close case; its "literate," artistic style might have saved it. Indeed, on appeal the government conceded as much. But under the revamped standards that was not enough. Moreover, the trial judge expressly found that only four of the fifteen articles appearing in the volume were obscene, ${ }^{87}$ and even these findings were by no means incontrovertible. ${ }^{88}$ What Ginzburg

[82.] Not until Jacobellis v. Ohio, supra note 15, did the concept of "variable" obscen. ity or obscenity per quod reappear. In Jacobellis, however, the Chief Justice and Mr. Justice Clark, dissenting, would have affirmed the conviction of a motion picture cxhibitor at least in part upon the ground that the film's advertising rendered the film itsclf obscene. Id. at $201 \mathrm{n} .2$. But Mr. Justice Goldberg, concurring, explicitly rejected the notion that "the exaggerated character of the advertising rather than the obscenity of the film is to be the Constitutional criterion." Id. at 198. Moreover, in Manual Enter. prises, Inc. v. Day, supra note 15, at 491, Mr. Justice Harlan, in an opinion announcing the judgment of the Court, said:

[N]either with respect to the advertisements nor the magazines themselves, do we understand the Government to suggest that the "advertising" provisions of [18 U.S.C.

$\S 1461]$ are violated if the mailed material merely "gives the leer that promises the

customer some obscene pictures." ... Such an approach to the statule could not

withstand the underlying precepts of Roth. (Emphasis supplied.)

[83.] 383 U.S. at 468 .

[84.] Id. at $470-71$.

[85.] See, e.g., id. at $470,471,474$.

[86.] 383 U.S. at 419.

[87.] 224 F. Supp. at 134-36.

[88.] See Brief for Petitioner, pp. 40-46, Ginzburg v. United States, supra note 7. In. deed, the government conceded that Eros presented "legitimate room for argument." Sce Brief for Respondent, p. 27, Ginzburg v. United States, supra. 
tried to do is, of course, evident. Roth required that the question of obscenity be determined on the basis of the "dominant theme of the book as a whole." Ginzburg sought to invoke that standard on the magazine level and to insulate Eros from condemnation by including within its covers some admittedly protected material, thereby preventing a judgment that, taken as a whole, any volume of Eros was without redeeming social value. On appeal, the United States did not go so far as to argue that on the magazine level the Roth standards should be applied on an article-by-article basis-a position which has much to commend it. ${ }^{89}$ Rather, the government argued that

in a publication, like Eros, which is a composite of independent works tied together only by the fact that they all treat sex in some manner, a judgment of obscenity as to the whole may thus be based upon some of its parts-so long as they are significant in light of the whole .... The opposite rule would, on the other hand, privilege obscene material because of its physical connection with non-obscene material..$^{90}$

The Court's response to the question of Roth's applicability on the magazine level is, to put it mildly, vague. Mr. Justice Brennan accepted the trial judge's finding that the inclusion of non-obscene material was a "deliberate and studied arrangement ... for the purpose of appealing predominantly to prurient interest," and that the record demonstrated that "Eros was created, represented and sold solely as a claimed instrument of . . . sexual stimulation." 01 But at this point his opinion suddenly trails off into obscurity:

Petitioners' own expert agreed, correctly we think, that "[i]f the object [of a work] is material gain for the creator through an ap. peal to the sexual curiosity and appetite," the work is pornographic. In other words, by animating sensual detail to give the publication a salacious cast, petitioners reinforced what is conceded by the Government to be an otherwise debatable conclusion. ${ }^{22}$

This, of course, is no answer. The case is not "close" simply because the

[89.] An "obscene picture of a Roman orgy vould be no less so bcause accompanicd by an account of a Sunday school picnic which omitted the offensive details." Flying Engle Publications, Inc. v. United States, 285 F.2d 307, 308 (1st Cir. 1961). A "person who mails a picture or pictures obviously obscene does not escape the condemnation of the statute by placing them in a package with other pictures not obscene." Collier v. United States, 283 F.2d 780, 782 (4th Cir. 1960). This position does not result in the loss of protected materials because the non-obscene material may be separately published.

[90.] Brief for Respondent, p. 31, Ginzburg v. United States, supra note 7.

[91.] 383 U.S. at 471.

[92.] Ibid. 
government "concedes" that it is. More importantly, Mr. Justice Brennan does not respond to the argument that the magazine must be judged as a whole, and that four of fifteen articles (themselves "close cases") do not render the book obscene.

The Court's sudden attempt to recast its obscenity doctrine in terms of a limited per quod theory raises problems of the sharpest order. As the dissents point out, ${ }^{03}$ it seems to fly in the face of the federal obscenity statute which apparently assumes an in rem approach-i.e., that the only question is the nature of the book itself.94 Certainly Congress had not explicitly directed its attention to the possible impact of production and advertising on the question of obscenity. The Court's construction of the federal statute not only redraws it so substantially as to suggest a denial of due process for lack of fair warning, ${ }^{05}$ but is also inconsistent with First Amendment traditions.

The Court has always insisted that restrictions on speech be embodied in precisely drawn legislation directed at specifically defined evils, and has invalidated statutes containing broad, sweeping language. ${ }^{77}$ Closer to the point here, the Court has reversed a conviction where a state court has attempted the narrowest "enlargement" of a statute beyond its plain terms. ${ }^{98}$ Plainly, the Court's construction of the federal obscenity statute has little in common with these decisions.

Ginzburg is an attempt to preserve the essence of Roth-that no serious work may be proscribed as obscene-and at the same time to permit the states to prosecute the commercial exploiters of erotica. It purports to rationalize this result by treating the commercial exploitation of erotica as relevant in a close case, which case, in turn, is resolved by the defendant's own "evaluation" or "admission" that his

[93.] 383 U.S. at 477 (Black, J.); id. at 498.94 (Harlan, J.).

[94.] Cf. MAss. GEN. Laws ch. $272, \S 28 \mathrm{~F}$, reprinted, 383 U.S. at 423-24. Sec also 383 U.S. at 417 n.3.

[95.] See Cole v. Arkansas, 333 U.S. 196 (1948). See also note 98 infra.

[96.] E.g., NAACP v. Button, 371 U.S. 415, 433 (1963).

[97.] Brown v. Louisiana, 383 U.S. 131 (1966); Cox v. Louisiana, 379 U.S. 536 (1965). In Ashton v. Kentucky, 384 U.S. 195, 200 (1966), Mr. Justice Douglas said:

Vague laws in any area suffer a constitutional infirmity. When First Amendment rights are involved, we look even more closely lest, under the guise of regulating conduct that is reachable by the police power, freedom of speech or of the press suffer.

[98.] In Bouie v. City of Columbia, 378 U.S. 347 (1964), the Court invalidated a conviction under a South Carolina criminal trespass statute forbidding "entry" upon the lands of another after notice from the owner prohibiting entry, which on appeal the state court construed for the first time also to include refusal to leave after notice. Bouie did not advert to First Amendment considerations, but only to the due process requirement of fair warning. But First Amendment considerations were close to the surface, since the case involved "sit-ins" protesting racial discrimination. 
work is obscene.99 These admissions are generally found in the circumstances of production and marketing. Over and over the Court emphasizes that defendant's "evaluation" of his work discloses that it lacks social value. ${ }^{100}$ But this refrain alone cannot harmonize obscenity per se and obscenity per quod. Under Roth, it is hardly self-evident that a book's social value is affected by the circumstances of its production or publicity, ${ }^{101}$ and to convict a publisher on the strength of his binding "admission" of obscenity is to indulge in the most naked of fictions. It is impossible to see why "admissions" should be binding only in "close" cases, ${ }^{102}$ nor why the "admissions" of a manufacturer should be binding on the First Amendment rights of his potential customers. ${ }^{103}$

While the Court has abandoned a straight Roth approach, it has still confined pandering evidence to "close cases" - that is, to cases involving books the social value of which is marginal. Thus we end up with the strange marriage of obscenity per se and obscenity per quod. The offspring of this marriage is the following: no serious or complex

[99.] See, e.g., 383 U.S. at 472:

[The petitioners] proclaimed its obscenity; and we cannot conclude that the court below erred in taking their own evaluation at its face value and declaring the book as a whole obscene despite the other evidence.

[100.] 383 U.S. at 470,471, 474-75. In Mfemoirs, Mrr. Justice Brennan noted that, "where the purveyor"s sole emphasis is on the sexually provocative aspects of his pub: lications, a court could accept his evaluation at its face value." 383 U.S. at 420 . And see Mishkin v. New York, 383 U.S. at 510.

[101.] Thus Mr. Justice Douglas, dissenting, observed:

The sexy advertisement neither adds to nor detracts from the quality of the merchandise being offered for sale. And I do not see how it adds to or detracts one whit

from the legality of the book being distributed. A book should stand on its own, irrespective of the reason why it was written or the wiles used in selling it.

383 U.S. at 482. And in Memoirs v. Massachusetts, 383 U.S. at 427, he said: "However florid [the book's] cover, whatever the pitch of its advertisements, the contents remain the same."

[102.] The leading exponents of variable obscenity see no reason to confine it to "close" cases:

$\ldots$ [I]n my judgment censorship should not depend upon the intrinsic nature of the material independent of its audience and method of marketing. Instead, it should depend upon the manner in which it is marketed and the primary audience to which it is sold. In this way constitutional protection an be given to the occasional legitimate distribution of hard-core pornography for scientific purposes, while at the same time censorship of material that is not intrinsically hard-core pornography can be permitted when the manner of marketing and the primary audience to which it is marketed indicate that it is being treated as hardcore pornography-lhat its function in that setting is to nourish erotic fantasies of the sexually immature. For these reasons I believe that obscenity should be a variable concept, depending upon the manner of marketing-the appeal in the marketing-and the nature of the primary audience to which the appeal is made.

Lockhart \& McClure, supra note 39, at 299.

[103.] Lamont v. Postmaster General, 381 U.S. 301 (1965), makes clear that potential receivers have First Amendment rights independent of their senders. Sce id. at 307.03 (Brennan, J., concurring). Yet, as a practical matter, the prosecution of the manufacturer in obscenity cases will foreclose the rights of the receiver as well. Sce Mrarsh v. Alabama, 326 U.S. 501, 505, 508-09 (1946). 
work may be suppressed as obscene, but a state has the power to suppress the business of manufacturing or distributing offensive erotica.

Despite Mr. Justice Brennan's protestations to the contrary, ${ }^{104}$ Ginzburg does result in some loosening of the social value test. In candor, Roth has proved inadequate and its rationale has been recast.

\section{Mishkin ข. New York ${ }^{105}$}

Like Ginzburg, Edward Mishkin was in the business of manufacturing and distributing erotica. But his business was of a somewhat different character. His books dealt not simply with sex, but with "sick" or aberrational sex. Sex was the focus around which sadistic and masochistic themes were elaborated. These so called "bondage" books can be found in any drugstore and most bookstores. They include such titles as Strange Passions, Hours of Torture, So Firm So Fully Packed, The Violated Wrestler, and Pleasure Parade No. 2. Mr. Mishkin was convicted on the rather staggering total of 141 counts of hiring others to prepare obscene books, possessing them and publishing them, all in violation of the New York criminal obscenity statute. He received a three-year prison term and $\$ 12,000$ in fines. The Supreme Court affirmed his conviction, three justices dissenting. ${ }^{100}$

What was only hinted at in Ginzburg comes clearly to light in Mishkin. Despite the Court's disclaimer, Mishkin's intent was controlling. He sought to engage in the business of pandering, and that can be proscribed, at least where the books involved possess only minimal social value. Once again Justice Brennan wrote for the Court, and his opinion shows the great leeway now permitted the state. He made little reference to questions of advertising or of "admissions." Rather, he treated the various parts of the New York statute as a unitary effort to eliminate the manufacture and distribution of sado-masochistic materials, and on that basis sustained the convictions. Justice Brennan said:

Appellant instructed his authors and artists to prepare the books expressly to induce their purchase by persons who would probably be sexually stimulated by them. ... Not only was there proof of the books' prurient appeal, compare United States $v$. Klaw, . . . but the proof was compelling; in addition appellant's own evalua-

[104.] Memoirs v. Massachusetts, 383 U.S. at 420; Ginzburg v. United States, 383 U.S. at $475-76$.

[105.] 383 U.S. 502 (1966).

[106.] Id. at 503-04. 
tion of his material confirms such a finding. See Ginzburg $v$. Uniled States. ...107

A few rationalizations may be offered. Unlike Ginzburg, the books involved in Mishkin did not present a "close" case. They were obscene per se. This analysis is not contradicted by the opinion. But Justice Brennan does not analyze the problem in those terms; he is centrally concerned with Mishkin's conduct, not the status of the books.

Mishkin's argument on appeal was principally restricted to the meaning of "prurient appeal." He made no effort to argue that his collection had social value. Thus, the Court was able to avoid dealing with a question of the most crucial importance: what is the "central meaning" of the social value test? But that question did not escape all notice. Dissenting in Fanny Hill, Mr. Justice White had pickishly inquired in passing why the fact that the books had a market did not demonstrate their social value. ${ }^{108}$ But it was left to Mr. Justice Douglas, dissenting in Mishkin, to lay bare the unexamined premises of the majority:

Some of the tracts for which these publishers go to prison concern normal sex, some homosexuality, some masochistic yearning that is probably present in everyone and dominant in some. . . . Why is it unlawful to cater to the needs of this group? They are, to be sure, somewhat offbeat, nonconformist, and odd. But we are not in the realm of criminal conduct, only ideas and tastes. . . . $[W]$ hy is freedom of the press and expression denied them? Are they to be barred from communicating in symbolisms important to them? When the Court today speaks of "social value," does it mean a "value" to the majority? Why is not a minority "value" cognizable? . . . If we were wise enough, we might know that communication may have greater therapeutical value than any sermon that those of the "normal" community can ever offer. But if the communication is of value to the masochistic community or to others of the deviant community, how can it be said to be "utterly without any redeeming social importance"? "Redeeming" to whom? $?^{109}$

Mr. Justice Douglas' questions cannot be brushed aside with the flourish that he misunderstands the social value test-that this test protects only the interest in the exchange of ideas, not other interests however significant. But does purely literary or artistic value qualify for protection?

[107.] Id. at 509-10.

[108.] Memoirs v. Massachusetts, 383 U.S. at 461 (dissenting opinion).

[109.] 383 U.S. at $489-90$. 
And even if the interests catalogued by Justice Douglas are not entitled to protection under the First Amendment, are they not sufficiently important to warrant some protection under the Due Process Clause? If so, what are the interests which the legislature found-or might have found, to use the traditional formulation-which require suppression of these books? The Court's opinion offers answers to none of these questions.

\section{Obscenity and The Law: Unfinished Business}

Plainly, the 1966 obscenity decisions are not the last word on the relationship between obscenity and the First Amendment. Like Roth, the 1966 cases could not reconcile the existence of obscenity prosecutions with a principled general theory of the First Amendment. Indeed, the 1966 decisions merely "adjust" Roth to permit the states considerable latitude in suppressing the commercial exploitation of erotica having minimal social value. Against this general backdrop one must assess some of the important legal problems which still demand resolution.

\section{Evidentiary and Related Problems}

The role of the judge in an obscenity prosecution is a critical evidentiary question bearing on the scope of First Amendment protection. The typical obscenity prosecution has been a trial of the book itself, even though in form a proceeding against the distributor or retailer. The earliest trials apparently amounted to no more than a submission of the book to the judge, but recent trials have featured elaborate evidentiary hearings. Fanny Hill illustrates the pattern. The Commonwealth introduced the book and the testimony of one marginally qualified expert. The defense introduced notices by literary critics, and the testimony of professors at Harvard, Brandeis, Williams, and Boston University, each of whom affirmed Fanny Hill's social value. Ginzburg involved an even more extensive hearing along the same lines. The critical question never faced under Roth was the scope of judicial review given records of this character. In the typical case, the trial judge heard the testimony as though he were being given a short course in English literature, but then made up his mind about the book quite independently of the record evidence. In Fanny Hill the amici urged the Massachusetts court to reject this approach and direct the trial judge to dismiss the prosecution so long as the record contained substantial evidence of the book's redeeming social value, unless the 
judge could conclude that the record testimony was irrational. ${ }^{110}$ Any other standard, they insisted, would give too narrow a protection to freedom of speech. Their argument is persuasive, and deserves better treatment than it received in last term's decisions.

The substantial evidence approach won support from two of the three dissenting judges in Massachusetts, ${ }^{111}$ and a subsequent opinion of that court involving Naked Lunch was more favorable.112 Unfortunately, however, the argument that the judge was bound by the record evidence was not pressed in the Supreme Court. In Ginzburg, the United States did argue, almost in passing, that the judge must make an independent determination on the question of obscenity. ${ }^{113}$ The decisions, in turn, contain little explicit discussion of this problem. Mr. Justice Harlan indicated that he was aware of and rejected the argument that the judge is bound by the "substantial" record testimony. ${ }^{114}$ Mr. Justice Douglas reached the opposite conclusion. ${ }^{125}$

[110.] See Brief of the Civil Liberties Union of Massachusetts. Attorney General $v$. A Book Named "John Cleland's Memoirs of a TWoman of Pleasure," 349 Mrass. 69, 206 N.E.2d 403 (1965).

[111.] Writing for himself and Justice Spiegel, Justice Whittemore summarized the evidence in favor of the book, and said:

It is not the court's function to consider whether to agree or disagree with the appraisal of the book by academic witnesses. The controlling circumstance is that the work is evaluated by representative scholars and teachers of English litcrature as a work of some literary and historical significance notwithstanding its patently pornographic aspects. $I$ construe the concept cmbodied in the term "social im. portance" as used by the United States Supreme Court to include the literary and historical field. Hence, I believe that the publication of this book is protected by the First Amendment as expounded in the Supreme Court decisions.

349 Mass. at 75, 206 N.E.2d at 407.

[112.] In Attorney General v. A Book Named "Naked Lunch,"__ Mass.—, 218

N.E.2d 571, 571-72 (1966), the court said:

As to whether the book has any redeeming social value, ... it appears that a sub. stantial and intelligent group in the community believes the book to be of some literary significance. Although we are not bound by the opinions of others concerning the book, we cannot ignore the serious acceptance of it by so many persons in the literary community.

See also United States v. Klaw, supra note 4, at 170: "[I]t is the record and not our feelings that must control."

[113.] See Brief for the United States, p. 24, Ginzburg v. United States, supra note 7. See also United States v. Kennerley, 209 Fed. 119, 121 (S.D.N.Y. 1913); People v. Fritch, 13 N.Y.2d 119, 125, 192 N.E.2d 713, 717, 243 N.Y.S.2d 1, 7 (1963). AIr. Ginzburg referred to the question of expert testimony, but only in terms of the generally accepted ctidentiary rules governing the use of such testimony. Brief for Petitioners, pp. 42-43. He made no attempt to develop a constitutional argument at this level.

[114.] 383 U.S. at 460 .

[115.] Id. at 427 .

It seems to me that the only solution that will fully protect First Amendment values is a holding that, confronted with substantial evidence of social value cither on the record or even outside it, the trial court must sustain a First Amendment defense. The suggested standard draws support from-but goes bejond-the general cvidentiary rules governing the role of expert testimony. While the trier of fact may not "arbitrarily" disregard all the expert testimony in the record and rely upon his unsubstantiated personal beliefs instead of upon evidence," Alvary v. United States, 302 F.2d 790, 794 (2d Cir. 1962), he may "reject expert testimony and reach a conclusion based upon [his] 
While Mr. Justice Brennan's opinion in Ginzburg does not treat the problem directly, it did sustain convictions over considerable record evidence that Eros as a whole, and each of the four questioned articles, had social value. ${ }^{116}$ Thus Ginzburg raises the question whether the book's social value must be "self-demonstrating" if pandering evidence is to be irrelevant. But if this is so, then record evidence will be of virtually no significance on the question of social value. In a clear case (where a book has obvious value), supporting evidence is superfluous, while in a "close" case (where social value is not obvious), the book will not be saved by the record testimony if it is being sold by a panderer. In other words, the only cases where record evidence would really be helpful are those where it will probably do no good. But this need not be the practical result of Ginzburg, for the Court did not squarely address itself to the standard by which the trial judge should evaluate the record testimony and, despite its implications, it should not be taken to have settled the point.117

knowledge, experience, and judgment. However, it must fairly appcar from the rccord that the fact finder had knowledge and experience relative to the subject matter." Cullers v. Comm'r, 237 F.2d 611, 616 (8th Cir. 1965).

I recognize, of course, that the substantial evidence rule is a principle governing judicial review of administrative determination of fact, not judicial findings in criminal trials; and I recognize that at least in federal prosecutions the question of social valuc is for the judge, not the jury. But I do not see that either of these observations means that the suggested standard raises constitutional difficulties. I do not believe that cven the most expansive reading of the "constitutional fact" doctrine of Crowell v. Benson, 285 U.S. 22 (1932), would result in invalidation of the suggested standard as a violation of Article IIr. Crowell dealt with legislative restrictions on judicial review, not with standards of review asserted to be part and parcel of the Biti of Rights. Sec generally JAFFe, Junictal Control of ADMiNistrative Action 636-56 (1965). I recognize that, unlike the substantial evidence test in administrative law, see Universal Camcra Corp. v. NLRB, 340 U.S. 474 (1951); JAFFE, supra, at 600-15, the proposed standard would requirc that the judge look only at the evidence supporting the book. This does not mean, however, that the judge could never fairly conclude that the expert testimony supporting the book was insubstantial. See, e.g., Books, Inc. v. United States, 358 F.2d 935 (1st Cir. 1966).

[116.] For a summary of this testimony, see Brief for Petitioners, pp. 4l-42, Ginzburg v. United States, supra note 7.

[117.] The Court has never addressed itself to the manner in which the trial judge should evaluate the evidence before him. Instead, it has tended to focus on the question of the extent to which it (or any appellate court) is bound by the finding of a lower court or administrative agency that a book is without social value. The Supreme Court has always considered its function to require it to make an independent judgment on the social value question, and in the 1966 cases all the parties agreed that this was its proper role. For a clear exposition of the view see Jacobellis v. Ohio, supra note 15, at 191 (opinion of Brennan, J.); United States v. West Coast News Co., 357 F.2d 855, 857 (6th Cir. 1966); United States v. Klaw, supra note 4, at 160 .

Mr. Justice Harlan, however, dissents from this view in part. He would set aside state court judgments only in "unusual" cases, 383 U.S. at 460 , where the judgment is a plainly unreasonable one. "From my standpoint," he says, "the Fourteenth Amcndment requires of a State only that it apply criteria rationally related to the accepted notion of obscenity and that it reach results not wholly out of step with current American standards." Id. at 458. This view rests on Mr. Justice Harlan's on-again-off-again "federalism"-his refusal to acquiesce in the view that the First Amendment applics to the states "in precisely the same fashion" as it applies to the federal government. Compare 
The Court has paid even less heed to evidentiary and appellate review problems stemming from the prurient appeal and patent offensiveness criteria. In Ginzburg the United States argued that the Court should independently review social value, but should accept the lower court's determination on pruriency and patent offensiveness unless clearly wrong. ${ }^{118}$ If adopted, this rule would still leave open difficult evidentiary questions. Must evidence be introduced on prurient appeal or is it a proper subject for judicial notice?119 Must patent offensiveness be "so gross as to be self-demonstrating," as Justice Harlan has suggested? ${ }^{120}$ To the extent that an obscenity prosecution involves other than "hard-core" pornography, expert testimony on patent offensiveness seems necessary. ${ }^{121}$ Certainly the patent offensiveness of Eros cannot fairly be characterized as "self-demonstrating." But if evidence is relevant on the question of national ${ }^{122}$ community standards,

Harlan, J., dissenting in Fanny Hill, 383 U.S. at 456, 458, with Harlan, J., silently joining the majority in New York Times Co. v. Sullivan, supra note l. The definitive rejection of the Justice's federalism approach came in Malloy v. Hogan, 378 U.S. 1, 5.6 (1964) (dictum). Cf. Pointer v. Texas, 380 U.S. 400 (1965). The difficulties with the Justice's analysis are examined in Kalven, supra note 15 , at 25.26. As a practical matter, the federalism view ends up somewhere between the balancing approach favored by Mir. Justice Clark and the thesis advanced by the Chief Justice in Jacobclis V. Ohio, supra note 15 , at 200-01 (concurring opinion), that obscenity should be treated as a "local" problem.

[118.] Brief for Respondent, pp. 27-28, Ginzburg v. United States, supra note 7.

[119.] The former is the approach taken in United States v. Klaw, supra note 4. But Klaw could be restricted to a requirement of proof in case of "deviant" or "csoteric" materials. Id. at 165 . While Mishkin dealt with materials of this nature, it vould seem that each new prosecution involving sadistic, masochistic or "esoteric" materials vould require separate proof of prurient appeal in order to justify restriction. See United States v. 1,000 Copies of Magazine Entitled "Solis," 254 F. Supp. 595, 597 (D. Md. 1960); cf. Noto v. United States, 367 U.S. 290 (1961). Perhaps, however, a defendant's "own evaluation" of prurient appeal may be enough under Mishkin. Thus, Mrr. Justice Brennan said:

Not only was there proof of the books' prurient appeal, compare Uniled States $v$.

Klaw ... but the proof was compelling; in addition appellant's own craluation of

his material confirms such a finding. See Ginzburg v. United States. 383 U.S. at 510 .

[120.] Manual Enterprises, Inc. v. Day, supra note 15, at 489.

[121.] Mr. Justice Harlan's opinions seem to be consistent with this view. In Fanny Hill he said that he would "characterize as 'hard core' that prurient material that is patently offensive or whose indecency is self-demonstrating .... 383 U.S. at 457. HC apparently believes that the "patent offensiveness" of hard-core pornograply" is "selfdemonstrating," but where the materials are not of that nature, proof must be forthcoming. Contra, Kalven, supra note 15, at 39. Cf. United States v. 1,000 Copies of Magazine Entitled "Solis," supra note 119.

I find no support for the view recently expressed by the Fifth Circuit in Chemline, Inc. v. City of Grand Prairie, 364 F.2d 721, 727 (1966), that "appeal to prurient interests" and "patent offensiveness" are equivalent concepts.

[122.] The various opinions in Jacobellis v. Ohio, supra note 15 , secmed to me to add up to "national," not "local" community standards. Mr. Justice Brennan's opinion in Jacobellis insisted that the "national" community is the relevant inquiry: Chicf Justice Warren reached the opposite result. In Fanny Hill the Chief Justice concurred in Mfr. Justice Brennan's opinion. Not surprisingly, therefore, the opinion does not refer to the 
what kind of evidence is it? ${ }^{123}$ Can the publisher introduce other books bought and sold in the market place as evidence of what national standards are? ${ }^{124}$ What of book reviews, or sociology studies? The Court has not addressed itself to any of these evidentiary questions, or, for that matter, to the proper relation between judge and jury in federal prosecutions. $^{125}$

matter of the appropriate community. It now seems to me that only four Justices arc definitely committed to the view that national community standards control: Black, Douglas, Brennan and Stewart, JJ. Mr. Justice Fortas may, therefore, be decisive on this issue.

I might add that my own preference is for the Brennan view. I am not insensitive to the difficulty of even believing that such a standard exists, let alone the difficultics in administering such a standard. But I cannot see that a book may be read in one community and not another; the First Amendment applies in Arkansas as well as in New York. My view is that if a book is not too offensive to be read by the residents of our great urban centers, it is not too offensive to be read by anyone else in the United States.

[123.] The only direct evidentiary references in the Supreme Court on community standards are to be found in the concurring opinions of Justices Frankfurter and Harlan in Smith v. California, 361 U.S. 147, 160, 169 (1959). Mr. Justice Harlan's view is that "while a state is not debarred from regarding the trier of fact as the embodiment of community standards, competent to judge a challenged work against those standards, it is not privileged to rebuff all efforts to enlighten or persuade the trier." Id. at 172. (Emphasis in original.)

[124.] So far at least, attempts by the publisher to supply the jury with other books have not met with great success. In Books, Inc. v. United States, 358 F.2d 935, 939 (Ist Cir. 1966), Judge Wyzanski said:

The other point deserving of our comment is the refusal of the trial judge to

permit defendant to introduce in evidence a large number of publications currently available in Rhode Island so that from them the jury could better form its opinion of community standards. It is, of course, true that what is sold in the market reflects to some extent community standards. But it is not true that every item sold is necessarily not obscene. Hence, not every book sold in the market is admissible to test the obscenity of Lust Job. Nor is a judge required to admit as a touchstone for the jury even those books which are admittedly not obscenc. The admission of a number of different publications alleged to be comparable to the publication in issue might make the trial unmanageably complex and lengthy. The trial judge must be allowed wide discretion as to whether to permit the intro. duction of such allegedly comparable publications, and as to whether to allow the witnesses to be examined in detail on publications other than the one directly at issue. Here the trial judge did not abuse his discretion.

In United States v. West Coast News Co., 357 F.2d 855, 860 (6th Cir. 1966), the district judge permitted defendants to select eight other comparable books allegedly accepted by contemporary community standards. Only two of the proferred eight were found comparable, and they were denied admission for lack of proof that they werc acceptable by community standards! See also People v. Finkelstein, 11 N.Y.2d 300, 305, 183 N.E.2d $661,663-64,229$ N.Y.S.2d 367, 371 (1962). United States v. 1,000 Copies of Magazine Entitled "Solis," supra note 119.

[125.] On the federal level, at least, obscenity cannot be characterized simply as a question of law for the court, United States v. Luros, $243 \mathrm{~F}$. Supp. 160 (D. Ia. 1963), or as a mixed question of law and fact to be submitted to the jury with instructions, Reed Enterprises v. Corcoran, 354 F.2d 519, 522 (D.C. Cir. 1965). Each of the three obscenity criteria must be separately considered. Despite the Court's lack of direct attention to the problem, it seems apparent that the question of social value is for the court alone. To the extent that they are not treated as matters of judicial notice, prurient appeal and patent offensiveness are for the jury. 


\section{Ginzburg at Retail}

The potential impact of the 1966 cases is also complicated by the fact that Ginzburg and Mishkin presented only one facet of the commercial exploitation of sex; they dealt with the suppression at the manufacturing, not the retail, stage of the business. Mr. Justice Brennan noted that manufacturers and distributors of erotica were not in any position to complain about the "residual vagueness" of obscenity. ${ }^{120}$ Whether they were or not, the same cannot be said of the retail seller, as Smith v. California ${ }^{127}$ recognized. There the Court invalidated the conviction of a book seller under an ordinance prohibiting the sale of obscene books on the ground that scienter was not required. The Court left open what mental element would suffice, but it recognized that imposition of strict liability would have disastrous consequences. ${ }^{123}$ Smith suggests that the states either confine their prosecutions to manufacturers and distributors, or adopt a procedure comparable to the Massachusetts in rem proceedings against the book itself, which allows criminal proceedings against retailers only after the book is adjudged obscene. The great advantage of the Massachusetts procedure is that it eliminates the vagueness otherwise inherent in a prosecutory scheme. ${ }^{22}$ Indeed, I was of the opinion that in rem proceedings were a constitutional requirement-part of the emerging First Amendment due process. Otherwise, fear of criminal prosecution would induce publishers and retailers to avoid the wide danger zone created by the definitional vagueness of obscenity. This self-censorship could deprive

[126.] 383 U.S. at 475 n.19.

[127.] 361 U.S. 147 (1959).

128. In a concurring opinion, Mr. Justice Frankfurter pointed out that a stringent scienter requirement would result in a practical overruling of Roth. 361 U.S. at 160.67. Under the Roth approach, Mr. Justice Frankfurter's criticism had merit. What was the mental element required under Roth, and was it required for cach of the thrce Roth criteria? For example, could the retailer show that he lacked knowledge that the book appealed to prurient interest or that it substantially exceeded national standards of community candor? See Kalven, supra note 15, at 37-39. And what of the social value test? To what extent was the bookseller under any obligation to familiarize himself with the contents of the book? Under Smith, is igmorance bliss? All these questions remained open under Roth.

[129.] Massachusetts has a criminal obscenity statutc, but as a matter of policy its Attorney General requires that all obscenity actions begin under the in rem procedure. The procedure is comparable to a criminal prosecution of a book publisher to the extent that the publisher is the principal-and generally the only-intervenor in the action. But there is the significant difference that if the book is held obscenc, no criminal penalties are imposed, and retailers will be criminally prosecuted only for activities after the book is adjudged obscene. The Massachusetts procedure is eminently desirable; it has the least possible impact on First Amendment interests. See MIAss. GEv. LAws, ch. 272, $\S \S 28 B-H$, set out as an appendix to the opinion of Mr. Justice Brennan in Memoirs $v$ Massachusetts, 383 U.S. at 421-24. 
the community of protected materials. But the 1966 cases indicate that the Court no longer entertains this view..$^{130}$

The retailer, however, is not in the same position as the manufacturer of erotica. As a practical matter he is unable to cope with the residual vagueness of obscenity, except by means of the most drastic self-censorship. ${ }^{131}$ Accordingly, if no prior in rem approach is constitutionally required, Smith should be strongly reaffirmed. The Court will have this opportunity in a number of cases involving prosecution of retailers which it has agreed to review. ${ }^{132}$ These new cases must, of course, take into account the sharp impact of Ginzburg and Mishkin on the mens rea question. Thus, if "appeal to prurient interest" means no more than sexual "stimulation," is the local seller on sufficient notice because he is selling Mishkin-type ("bondage") books, whose covers alone spell out their probable content? And is the cover-or general class of the booksufficient to warn the retailer that it lacks social value? ${ }^{133}$ And, of course, if patent offensiveness is not properly a matter for judicial notice, what kind of evidence must the state introduce on the question of national community standards? In any event, can the retailer clefend on his lack of knowledge of community standards?

The difficulty of the foregoing questions will be aggravated because of the Court's enlargement of the obscenity statute to embrace the manner in which a book is advertised. Lacking legislative guidance, the Court must define the kind of advertising indicating an "admission" by the publisher that the book is not entitled to First Amendment protection. Is it sufficient that the cover alone have the "leer of the sensualist"? 134 What of advertising with the quiet "leer of the sensualist"? ${ }^{135}$ More to the point, what is the relationship between the

[130.] If Ginzburg and Mishkin concede power to the states to suppress the commercial exploitation of sex, such suppression can be accomplished only at the manu. facturer-distributor level. Innumerable retail prosecutions seem to me both wasteful and unfair.

[131.] "One assumes that if the Court itself no longer knows how to define obscenity, it can hardly expect the clerk to do any better." Epstein, The Obscenity Business, Thic Atlantic Monthly, August 1966, p. 59.

[132.] See Redrup v. New York, App. Term, Sup. Ct. N.Y., 1st Jud. Dept. (unreported), cert. granted, 384 U.S. 916 (1966); Austin v. Kentucky, Civ. Ct. McCracken Co., Ky. (unreported), cert. granted, 384 U.S. 916-17 (1966).

[133.] In this respect, it should be recalled that the advertising itself need not be obscene. In Ginzburg the government conceded that the advertising was not obscenc, so that a book not itself obscene marketed by advertising also not obscene may result in a conviction for violating an obscenity statute.

[134.] See Books, Inc. v. United States, 358 F.2d 935, 938 (1st Cir. 1966).

[135.] Consider The Story of $O$, said to be one of the most pornographic books ever written. This book is marketed in a plain white cover with the title alone appearing on the front page. An advertisement showing only the cover of the book appeared in the New York Times accompanied by a book review describing its erotic qualities. Sec, e.g., New York Times, August 28, 1966, Literary Supplement, p. 21. 
advertising of the publisher or the distributor on the one hand and that of the retailer on the other? ${ }^{130}$ Can the advertising of the distributor be "imputed" to the retailer? Suppose one panders and the other does not? Whose advertising will be decisive? Or suppose that, as is sometimes the case, a book appears in both hard cover and paperback editions from different publishers, or appears in more than one paperback edition? Must the prosecution show that the publisher's advertising affected customers-or potential customers-of the retailer being prosecuted?

\section{Conclusion}

Like Roth, the 1966 cases do not succeed in fitting obscenity prosecutions within any comprehensive theory of the First Amendment. But, in principle, they do permit the states wide leervay to move against the commercial exploiters of erotica. Their actual impact is, of course, difficult to assess at this juncture. But, as Professor Emerson reminds us, repression takes place in a live context, and "those who are assigned the task already have or soon develop a tendency to pursue it with zeal." ${ }^{137}$ Any ground yielded to the censor unquestionably means that he will demand more. It is, therefore, safe to assume that the censors will take the 1966 decisions as further encouragement to go about their good works. ${ }^{138} \mathrm{But}$, as yet, obscenity prosecutions are still of marginal concern; it still remains unlikely that any "significant" book will be suppressed. That may not be enough, but it is a good deal.

[136.] In an in rem proceeding against the book under the Mrassachusetts obscenity statute, the book may be banned in partial reliance on the manner of its adrertising. If the advertising ceases, may a retailer then sell the book? On principle, it would seem so, since the status of the book apart from its advertising has not been adjudicated. But the wary bookseller may not be so willing as the legal observer to indulge in such nice distinctions; for him the cost of error is far too great.

[137.] Emerson, supra note 10, at 890.

[138.] And it should be noted that several judges have expressed sympathy with vigorous censorship programs. Thus, in United States v. West Coast News Co., 35i F.2d 855 (6th Cir. 1966), the court said:

We applaud and share the desire of the learned District Judge in this case to strike at and slow down the ever-increasing relocity of today's commerce in obscenity. Id. at 865 .

The court, however, boggled at the district judge's imposition of sentences totalling 25 years.

In his usual colorful style, Justice Mrusmanno warns us:

a wide river of filth is sweeping across the nation, befouling its shores and spreading over the land its nauseating stench. But, what is most disturbing of all, is that persons, whose noses should be particularly sensitive to this olfactory assault do not smell it at all. I refer to district attorney and prosecuting offeers throughout the nation. Of course, there are a large number of district attorneys in the countr; who are doing their duty and doing it well, but a langer number of prosecuting officials are shrugging unconcerned shoulders at this violent assault on law, moralit; and decency.

Address by Justice Musmanno, October 23, 1965. Compare United States v. Klaw, supra note 4; and see Kalven, supra note 15, at 45. 
The Board of Officers of Volume 76 wishes to mark the retirement of its predecessor with congratulations for an excellent volume.

With this issue The Yale Law Journal changes its format and design. Graphic design is by Marcia McGinnis.

\section{Friends of the Yale Law Journal}

On Saturday, April 1, 1967, the Yale Law Journal will hold its Seventy-Sixth Anniversary Banquet. The guest speaker will be the Hon. John Doar, Assistant Attorney General; the toastmaster will be Professor Alexander M. Bickel of the Yale Law School faculty. Lawyers, judges, alumni, and other friends of the Journal may make reservations now by sending a note to the Business Manager, Yale Law Journal, 401A Yale Station, New Haven, Conn. 


\section{The Yale Law Journal}

Volume 76, Number 1, November, 1966

\section{Editor-in-Ghief \\ Note \& Comment \\ Editors}

Projects Editor

Article ì Book

Review Editors

Topics Editor

Managing Editor

Bruge A. Ackeritan

LEONARD H. BECRER

STEPHEN V. BOMSE

RUSSELL CARPENTER

Altan GHapin

BARRX G. Craig

Marvin J. Diamond

ARden Doss, JR.

VIRGINLA B. EISENSTEIN

John Miles Evans

David B. Gerber

RICHARD GOODYEAR

ThoMras Grey

David W. Hess

ALAN C. HOOKER
LEONARD M. ROSS

H. JEFF GREENFIELD

SIMron LAZARUS III

JOSEPH N. ONEK

SILAS WASSERSTROAI

MIIchael S. Wald

Leonard Chazen

Philip Gordon Schrag

Charles H. Hierz

Thoncas Haniltox Childers, Jr.

\author{
MARK SCILANTZ \\ ERIC SCHNAPper \\ Jorn E. Sanurz \\ Atan D. Sismssi: \\ Allan G. Speruing \\ MIIGinat. T. StapletoN \\ JOEE. TV. StERAMaAN \\ EDWARD L. StRoHDEHs; JR. \\ Robert B. TANiner \\ David F. Tilcotson \\ CharLes H. TWHTtEdREAd II \\ HARDY TWIETING, JR. \\ JEFFREY TYOOD \\ HENRY L. WOODWARD \\ MLATtiew Zwerling
}

Business Secretary M. OLIVE Butterfield

Student Contributors to This Issue

Matthew Zwerling, The Selective Service

Bruce A. Ackerman, Constitutionality of Export Controls

Robert B. Tanner, Dues Disputes Under the Railway Labor Act 